\title{
Revised Trauma Score (RTS) as a Mortality Predictor for Heavy Head Injury Patients (in IGD) PKU Muhammadiyah Gombong Hospital
}

\author{
Isma Yuniar' ${ }^{1}$ Evi Suwarsih ${ }^{2}$, Endah Setianingsih ${ }^{3}$ \\ \{ismayuniar@gmail.com ${ }^{1}$ \} \\ Muhammadiyah Gombong Health Institute, Indonesia ${ }^{1,2,3}$
}

\begin{abstract}
The phenomenon of high head injury and a large mortality rate is in the spotlight. Knowing the prognosis of head injury by conducting an initial assessment or accurate system scoring is very important to know the progress, worsening of the patient's condition. The Revised Trauma Score (RTS) is a trauma scoring system that assesses physiological functions capable of predicting the death of head injury patients. PKU Muhammadiyah Gombong Hospital in identifying trauma patients has not used trauma scoring specifically for trauma. Analyzing and identifying using only the observation sheet has not been able to show the severity of the injured or traumatized patient. The purpose of this study was to determine whether RTS was effectively used to predict mortality in severe head injury patients. This research method is a type of descriptive correlation research using a retrospective cohort study approach by taking medical record data from 2015 to 2019 . Retrieval of data using observation sheets was carried out on April 20, 2020, at PKU Muhammadiyah Gombong Hospital. The study sample consisted of 87 patients with severe head injury according to the inclusion and exclusion criteria. Test Results of the 'Statistics Test' known as Asymp.Sig. (2-tailed) on the Fisher's Exact Test of $(0.683>0.05)$. Thus the Revised Trauma Score (RTS) statistical test is not effective against the Predictors of death in severe head injury patients at PKU Muhammadiyah Gombong Hospital. Recommendations Researchers can then add nursing and medical interventions as other considerations.
\end{abstract}

Keywords: Mortality, severe head injury patient, RTS

\section{Introduction}

The phenomenon of trauma or injury is a case that is often found in the Emergency Room (IGD) Hospital. Trauma is closely related to disability and death rates. Trauma or injury cases often occur due to traffic accidents. Traffic accidents often occur in developing countries such as Indonesia, whose numbers are increasing in proportion to the development of industry and transportation.

In 2002 one kind of cause accidents that caused many deaths in world traffic accidents $(22.8 \%)$ followed number two with unintentional accidents $(18.1 \%)$ and number three due to suicide $(16.9 \%)$. Meanwhile in India there are also traffic accidents was the leading cause of death $(31 \%)$. On the year 2000 accidents on the highway became the number nine cause of death in the world and the fifth leading cause of death in the United States. In the world this figure will always be increasing and on the year 2020 is expected to be traffic accidents to be the 
number three cause of death after ischemic heart and depression with projections accidents from 5.1 million in 1990 to 8.4 million in 2020

According to WHO [13], Indonesia fifth ranks with a total traffic accident victim of 38,279 people in 2015. Traffic accidents in 2016 amounted to 106,747 people (Central Statistics Agency, 2016). The number of traffic accidents in Central Java province in 2016 was still quite high, reaching 4,875 incidents. In 2018, the number of traffic accidents in Central Java was still relatively high at 72,700 people and the proportion of head injuries due to accidents was 10,000 people [7].

Many tools for polytrauma care exist for better management of these patients, as well as to provide predictive factors of morbidity and mortality to generate statistical data for the establishment of preventive measures to trauma. There are several trauma scores, with different levels of complexity for practical implementation. The Revised Trauma Score (RTS) is widely used by emergency services around the world

The scoring system has changed since the beginning of its inception. Some of the scoring systems available include the Revised Trauma Score (RTS), Injury Severity Score (ISS), and Trauma-Related Injury Severity Score (TRISS). This scoring system was chosen because it is often used in trauma research articles.1,4 RTS assesses the human physiological system as a whole, is the result of a refinement of the GCS instrument to assess the initial condition of head trauma patients. RTS assessments are performed immediately after the patient is injured, generally before admission to the hospital or while in the emergency room. The RTS necessitates the use of a formula to admit the GCS, respiratory rate and systolic blood pressure and it remains the most commonly used pre-hospital trauma scoring system. Moreover, the RTS is considered as one of the most easily calculated triage tools available shortly after trauma admission.

Regarding the condition of head injury patients with skull fractures, it was explained that GCS is an important scale to assess the initial level of consciousness or physiological status, clinical condition and even the prognosis of the patient's condition [3]. Systolic blood pressure is a good predictor of mortality in head injury patients [5] because it can assess systemic changes such as the incidence of hypotension. Apart from GCS and systolic blood pressure, respiratory status is also important. Unconsciously, the body will try to meet oxygenation, maintain perfusion of brain tissue and maintain cerebral hypoxia [4]. Respiratory rate less than 12 times per minute or less than 24 times per minute will increase the risk of death in head injury patients, in other words, it has a bad outcome [9].

Based on the description of the events above, the experts developed a trauma scoring system. The trauma scoring system is part of the initial assessment by looking at the physiological function or physiological status of humans as a whole which was developed by Champion et al. [2] in 1989. The trauma scoring system has 3 parameters, namely the level of consciousness, respiration, and systolic blood pressure. The sum multiplied by the rebellion obtained the value of the risk of patient deterioration. RTS values ranged from 0-7,804 from heavy to light. The lower the RTS value, the worse the patient's condition and the value $<4$ patients should be referred to a trauma center hospital.

Several studies that studied the relationship between RTS and mortality within the first 24 hours at the hospital showed that there was a significant relationship, RTS had $88 \%$ and specificity $90 \%$ (Heydari, 2013). In the research of Ranti et al., (2016) RTS is easy to apply during the triage and pre-hospital phase, or in the ER and is recommended to be part of the guidelines for handling multi-trauma cases.

On the RTS calculation formula, the greater constant multiplies the Glasgow Coma Scale, the SBP and RR being multiplied by lower constants. From this, victims of neurological trauma, 
whose GCS values are smaller, will have a lower final RTS result and be classified as potentially more severe. In contrast, patients with thoracic or abdominal trauma, which at first may not display changes in the level of consciousness, may result in an overestimated RTS value, apparently not predicting gravity. This failure in the evaluation of such patients may not correlate well with the actual clinical situation and case seriousness, often not demanding more specialized staff, which may impair the patient's progress.

Based on the results of the analysis at PKU Muhammadiyah Gombong Hospital in identifying trauma patients, they only use a few criteria to identify the severity of the trauma. They have not been able to show the severity of the injury or trauma patient, the prognosis, and even the patient's death. From this phenomenon, the researchers wanted to know the extent to which RTS could be effective as a predictor of death in severe head injury patients at Muhammadiyah Gombong Hospital.

\section{Method}

This research is a descriptive correlation research type using a retrospective cohort study approach by taking medical record data from 2015 to 2019. Using the observation sheet, it was conducted on April 20, 2020, at PKU Muhammadiyah Gombong Hospital. The study sample consisted of 87 patients with a severe head injury in accordance with the inclusion and exclusion criteria.

Data is taken by recording the number of respondents with severe head injuries from January 2015 to December 2019 then looking at the mortality data for that period of the year and recording respiration, blood pressure, and level of awareness (GCS) data on the triage sheet from the respondent's medical record. After all the components of the RTS data were collected, the researcher calculated the respondents one by one using the RTS formula when the patient was diagnosed with a severe head injury for the first time. Data taken from patient observation sheets, the measurement results are the initial examination of the patient arriving at the Emergency room

Univariate analysis in this study was for severe head injury patients such as the characteristics of the respondents in this study, namely gender, age, occupational vital signs regarding the Glasgow Coma Scale (GCS), Systolic Blood Pressure (SBP), and Respiration Rate (RR) of respondents presented in the frequency distribution (percentage). Bivariate analysis in this study was used to determine the effectiveness of RTS on the predictors of mortality in severe head injury patients using Chi-Square test analysis.

\section{Result and Discussion}

\subsection{Presenting the results}

Based on the findings of this study, the characteristics of head injury patients were severe (Table 1) 
Table 1. Frequency Distribution of Characteristics of Respondents

\begin{tabular}{lll}
\hline Characteristics & of & $\mathrm{N}=87$ \\
\cline { 2 - 3 } Respondents & Frequency (f) & Percentage (\%) \\
\hline Gender & & \\
Male & 65 & 74.7 \\
Female & 22 & 25.3 \\
Age & & \\
Adolescence & 22 & 25.3 \\
Adult & 25 & 28.7 \\
Elderly & 28 & 32.2 \\
Senior & 12 & 13.8 \\
Worker & & \\
Labor & 18 & 20.7 \\
IRT & 9 & 10.3 \\
Farmer & 15 & 17.2 \\
PNS & 3 & 3.4 \\
Driver & 1 & 1.1 \\
Private & 9 & 10.3 \\
Not Working & 23 & 26.4 \\
Self Employed & 9 & 10.3 \\
\hline
\end{tabular}

Based on the table 1 that most of the severe head injury patients were male $(74.7 \%)$ amounted to 65 , the majority of severe head injury patients were elderly $(32.2 \%)$ of 28 people. The dominating job was not working $(26.4 \%)$ of 23 people.

Table 2. Frequency distribution of GCS values in severe head injury patients.

\begin{tabular}{lll}
\hline & $\mathrm{N}=87$ & \\
\cline { 2 - 3 } & $\mathrm{f}$ & $\%$ \\
\hline GCS & & \\
0 & 27 & 31.0 \\
1 & 19 & 21.8 \\
2 & 41 & 47.1 \\
3 & 0 & 0.0 \\
4 & 0 & 0.0 \\
SBP & & \\
0 & 0 & 0.0 \\
1 & 1 & 1.1 \\
2 & 5 & 5.7 \\
3 & 4 & 4.6 \\
4 & 77 & 88.5 \\
RR & & \\
0 & 3 & 3.4 \\
1 & 0 & 0.0 \\
2 & 2 & 2.3 \\
3 & 21 & 24.1 \\
4 & 61 & 70.1 \\
\hline
\end{tabular}

Based on Table 2, the GCS score of severe head injury patients found that the GCS results of severe head injury patients were found the majority of GCS results have a score of 2 (6-8) of 41 people $(47.1 \%)$. The SBP of severe head injury patients had the highest score of $4(>89)$ as 
many as 77 people $(88.5 \%)$ and the majority of severe head injury patients had a respiration rate score of $4(10-29)$ as many as 61 people $(70.1 \%)$.

Table 3. Distribution of RTS results in severe head injury patients.

\begin{tabular}{lll}
\hline RTS degrees & & $\mathrm{f} \%$ \\
\hline Heavy & 6 & 6.9 \\
Medium & 81 & 93.1 \\
& $\mathrm{~N}=87$ & \\
\cline { 2 - 3 } & &
\end{tabular}

From the results of statistical calculations, patients with a severe head injury had a minimum score of 26 284, the value of the maximum score 59672. Value degrees RTS severe head injury patients with severe risk score $(<3.4)$ of 6 people $(6.90 \%)$, moderate risk $(3,4-7,2)$ 81 people $(93.1 \%)$.

Table 4. Frequency Distribution of the Relationship between Revised Trauma Score (RTS) against Predictors of Mortality in Patients Serious Head Injuries $(\mathrm{N}=87)$

\begin{tabular}{|c|c|c|c|c|c|c|c|}
\hline & & & & & \multicolumn{2}{|c|}{ Predictors of } & \multirow[t]{2}{*}{ Total } \\
\hline & & & & & $\varlimsup$ life & & \\
\hline \multirow[t]{4}{*}{$\overline{\mathrm{RTS}}$} & \multicolumn{2}{|c|}{ Weight Risk } & \multicolumn{2}{|c|}{ Count } & 2 & mortality & $6 \%$ \\
\hline & & & \multirow{3}{*}{\multicolumn{2}{|c|}{$\begin{array}{l}\text { of total } \\
\text { Count } \\
\% \text { of the total }\end{array}$}} & $2.3 \%$ & $4.6 \%$ & $69 \%$ \\
\hline & \multirow{2}{*}{\multicolumn{2}{|c|}{ Moderate Risk }} & & & 40 & 43 & 83 \\
\hline & & & & & $43.7 \%$ & $49.4 \%$ & $93.1 \%$ \\
\hline \multirow[t]{3}{*}{ Total } & & & \multirow{2}{*}{\multicolumn{2}{|c|}{$\begin{array}{l}\text { Count } \\
\% \text { of the total }\end{array}$}} & \multirow{2}{*}{$\begin{array}{l}40 \\
46.7 \% \\
\end{array}$} & 47 & 87 \\
\hline & & & & & & $54.0 \%$ & $100.0 \%$ \\
\hline & & Value & $\mathrm{df}$ & \multicolumn{2}{|c|}{$\begin{array}{l}\text { Asymptotic } \\
\text { Significance } \\
\text { (2-sided) }\end{array}$} & $\begin{array}{l}\text { Exact Sig. } \\
\text { (2-sided) }\end{array}$ & $\begin{array}{l}\text { Exact Sig. } \\
\text { (1-sided) }\end{array}$ \\
\hline \multicolumn{2}{|c|}{$\begin{array}{l}\text { Pearson Chi- } \\
\text { Square }\end{array}$} & $.415^{\mathrm{a}}$ & 1 & .520 & & & \\
\hline \multicolumn{3}{|c|}{ Fisher's Exact Test } & & & \multicolumn{2}{|c|}{.418} & .683 \\
\hline \multicolumn{3}{|c|}{$\mathrm{N}$ of Valid Cases 87} & & & & & \\
\hline
\end{tabular}

Based on the analysis of "Test Statistics", it is known that Asymp.Sig. (2-tailed) on the Fisher's Exact Test of (0.683) means $\mathrm{p}>0.05$.

\subsection{Discussion}

The results of the study showed that the most results were gender. male (74.7\%) amounted to 65 , the category of the male sex is quite dominant. This is because men have an active role in taking action on the road and high mobility in driving, while the awareness to maintain safety is low [1].

Most of the patients with severe head injury are in the elderly phase, namely the age of 4665 years. The increasing age of a person at the same time will be followed by reduced visual function and decreased physiological system. So that it is more at risk of getting in danger from its decreased reactions [1]. The predominant occupational criteria from the research results are adolescence, adulthood because many of these ages are still students. In line with the results of 
Wahyudiyanto's (2014) research, the characteristics of the type of job in the non-working category have a more dominant value, namely $36.8 \%$, as many as 28 people because many of them are students.

The results showed that the physiological status of severe head injury patients included GCS, SBP, and RR. GCS of severe head injury patients has the highest score with a score of 4 (6-8). The results of the analysis show that the GCS values of severe head injury patients range from 3 to 8. In line with Krisanty (2009), the GCS of severe head injury patients ranges from a range of values. 3 to 8 and the patient has decreased consciousness for more than 24 hours or even days. The measurement of GCS is indirectly to show the level of brain function as a control function of all human organs and as a measuring tool for the severity of head trauma patients (Ting et al., 2010).

According to Irawan et al., (2010), the assessment of GCS depends on the patient's body reflexes, on the cerebral response to afferent stimuli. Low physiological status is not different from the physiological status of a serious or serious condition so it requires fast, precise and accurate action to minimize the high mortality rate. In line with Brazinova et al (2010), GCS can influence patient prognosis. The smaller the GCS value, the worse the prognosis of head injury patients.

Moreover, other physiological status values such as SBP and RR will also be seen because in a decreased or low neurological status the physiological status changes as compensation. The results of the data analysis showed that the SBP of severe head injury patients had the highest score at $4(>89)$ as many as 77 people $(88.5 \%)$.

From the results of data analysis of patients with a severe head injury, the majority of patients experienced a decrease and an increase in systolic blood pressure. In trauma patients including severe head injury, hypotension can occur at any time. According to Arnold (2013), the incidence of hypotension can increase the mortality rate. Among the head injury patients, patients were hypotensive due to massive blood loss in the systemic system. In the initial conditions of head trauma, the body reflexively tries to increase blood pressure to maintain the reflexively Cerebral Perfusion Pressure (CPP) [8].

According to research by Berry et al. (2012) and Fuller et al. (2014), blood pressure $<120$ $\mathrm{mmHg}$ has 1.5 times the risk of death, $<100 \mathrm{mmHg}$ has 2 times the risk of death, $<90 \mathrm{mmHg}$ has 3 times the risk of death and 6 times the risk of death at blood pressure $<70 \mathrm{mmHg}$. A decrease in SBP in head injury patients is an indication that there is an increase in the severity of these patients.

Based on the study, the RR value in patients with a severe head injury, the majority of which had a respiration rate score of $4(10-29)$, was 61 people (70.1\%). From the results of the analysis, the researchers assumed from the research analysis that patients who had high respiration frequency values were close to abnormal because they were trying to maintain Cerebral Perfusion Pressure (CPP) by maintaining blood pressure within the normal range.

Changes in respiratory rate can cause a decrease in the value and quality of oxygen saturation and decreased perfusion to the tissues, the brain does not get oxygen supply which results in cerebral hypoxia. Thus, according to Ristanto et al [8], the outcome of treatment of head injury patients is bad. This research is different from that conducted by Widyaswara et al. [12] states that there is no relationship between respiratory frequency and outcome of head injury patients, but in the discussion of respiratory frequency, it is stated that respiratory frequency is an indicator of head injury patient outcomes that can be used. An increased respiratory rate (hyperventilation) occurs at the beginning of the trauma or head injury phase to maintain oxygen saturation. 
Predictors of death in patients with severe head injury based on the results of the analysis obtained, in the first 24 hours (54.0\%) 47 people and death more than 24 hours or patients alive (46.0\%) 40 people. The deaths here are dominated by adults and the elderly because they have mobilized outside the home and even on the road and have a greater risk of accidents and even death. Besides, they also have an abnormal physiological status, meaning they have a fairly poor prognosis.

Another factor is also due to having bad vital signs such as GCS, SBP, RR values at the onset of trauma. GCS measurement indirectly indicates the patient's neurological function. The smaller the GCS value, the worse the prognosis of head injury patients. This statement is evident from the results of the study to get a GCS value of $\leq 8$ or with a total death of $54.0 \%$. In line with Ristanto's et al [8], in his study, patients who died had a GCS value of $\leq 8$ by 19 people (79\%). The next factor is systolic blood pressure or SBP, systolic blood pressure in patients with severe head injuries, many of which have values below normal or fall into the hypotension category, namely 45 people $(50 \%)$.

These results are consistent with research by Berry et al. (2012) and Fuller et al. (2014); Ristanto et al [8], that patients who have blood pressure $<120 \mathrm{mmHg}$ have 1.5 times greater risk of death, $<100 \mathrm{mmHg}$ have a 2-fold risk of death, $<90 \mathrm{mmHg}$ has 3 times, $<70 \mathrm{mmHg}$ has 6 times folding.

When the patient is hypotensive or the diastolic blood pressure is below normal, the patient may experience bleeding. Low CPP causes new problems, namely ischemia and causes infarction of brain tissue. According to Irawan et al. (2010); Ristanto et al [8], SBP $<90 \mathrm{mmHg}$ is associated with higher mortality rates. Another factor of death for the first 24 hours is a decrease in oxygen saturation $<90 \%$ (Kellet et al. 2008; Putra DSE et al., 2016). The decrease in oxygen saturation is due to changes in respiratory frequency, both the frequency increasing above normal and even decreasing below normal.

The severity of the RTS score in this study showed that the statistical calculation of severe head injury patients had a minimum score of 26284, a maximum score of 59672. The RTS grade of severe head injury patients with a severe risk score $(<3,4)$ was 6 people $(6,90 \%)$, moderate risk $(3,4-7,2) 81$ people $(93.1 \%)$ mean RTS score of around 4.9218 , both dead and alive severe head injury patients. In the study by Subhannur et. al. [6], 11 people (10\%) had moderate risk RTS severity scores who died, 41 people (38\%) had a low-risk score, the difference with this study was that there was no RTS severity score. mild risk. In accordance with Champion's [2] theory that the heavier the RTS score, the higher the mortality rate in the first 24 hours, meaning that severe head injury patients with a severe risk RTS score $(<3,4)$ have a higher prognosis.

From the analysis of "Chi-Square Test," it is known that Asymp.Sig. (2-tailed) on the Fisher's Exact Test (0.683) p value $>0.05$, that the hypothesis is rejected. Thus statistically the Revised Trauma Score (RTS) test is not effective against predictors of death in severe head injury patients at PKU Muhammadiyah Gombong Hospital.

RTS was effective in predicting the sample overall mortality, the majority of cases displaying RTS above seven, which indicates a high probability of survival. However, when compared groups, RTS was more effective in analyzing the survival rate in patients suffering from traumatic brain injury than doing so for patients with penetrating and blunt trauma to the chest and abdomen.

In other words, the revised trauma score can act as atriage tool to predict mortality and prioritize the care oftraumatic patients with different intensities especiallywhen dealing with lack of resources, but it is not enoughas the only used tool. Application of other tools may improve the value of mortality prediction in traumatic patients and minimize the possibility of error in prioritizing and care of patient. The usage of only the first revised trauma score and 
measurement of mortality within the first $24 \mathrm{~h}$ of hospitalization were two limitations of this study.

In this study, in line with Wahyudianto et al. [11], the data was obtained from a p-value of 0.310 so that $\mathrm{p}>0.05$, so Ho was accepted and $\mathrm{H} 1$ was rejected, meaning that there was no significant relationship between RTS and mortality in head injury patients at RSUD. Picture of Kediri City in 2014.

Reflexively, the body will try to meet oxygen needs, maintain perfusion of brain tissue and prevent hypoxia by increasing the frequency of respiration and maintaining SBP within normal ranges. Researchers assume based on the analysis of patients with severe RTS scores but did not die in the first 24 hours because the patients were able to maintain their SBP, RR scores even though the GCS scores were low. Other factors regarding intervention in meeting physiological needs in an emergency such as patenting of the airway, meeting oxygenation needs, maintaining cardiovascular conditions and handling $<6$ hours that have been done so that the systemic system and perfusion are still under control.

There are several limitations of the study, the researcher is unable to refute the statements of the research results including nursing or medical interventions, supporting examinations, the patient's medical history.

\section{Conclusion}

The results of this study concluded that statistically there was no significant relationship between RTS and the predictors of mortality in severe head injury patients. However, the lower the RTS value, the greater the risk of death in the first 24 hours. For this research, the hospital can be used as consideration for usage and additional references. The next researcher can add a history of the disease, nursing interventions.

\section{References}

[1] Aprilia Hanura. (2017). Gambaran Status Fisiologis Pasien Cedera Kepala di IGD RSUD Ulin Banjarmasin. Dinamika Kesehatan, Vol. 8 No 1.

[2] Champion, H.R. (1989). A revision of the Trauma Score. Us National Library of Medicine. http://www.ncbi.nlm.nih.gov/pubmed/2657085.diakses pada Tanggal 19 Oktober 2019.

[3] Lingsma, H., Rozzenbeek, B., Steyerberg, Murray, G., \& Maas, A. (2014). Early prognosis in traumatic brain injury: from prophecies to predictions. Lancet Neurol, 9, 543.

[4] Manley, TG et al. (2012), Early management of severe traumatic brain injury, Journal of the Lancet, 380 (9847), 1088-98.

[5] Perel, P. (2012), Predicting early death in patients with traumatic bleeding: development and validation of prognostic model, BMJ, 345.

[6] Rahman Subhannur, Al Kahfi Rina, Santoso Rahmat B., Kustanti Dian. (2017). Efektifitas RTS dan GAP untuk Memprediksi Kematian Pasien Cedera Kepala di Gawat darurat Rumah Sakit Bangsal Ulin Banjarmasin. Atlantis Press. Kemajuan dalam Penelitian Ilmu Kesehatan, volume 6.

[7] Riskesdas. (2018). Jakarta: Badan Penelitian dan Pengembangan Kesehatan, Departemen Kesehatan, Republik Indonesia.

[8] Ristanto Riki, Indra MR, Poeranto Sri, Setyorini Ika. (2016). Akurasi Revised Trauma Score sebagai Prediktor Mortality Pasien Cedera Kepala Jurnal Kesehatan Hesti Wira Sakti, Volume 4, Nomor 2, Oktober 2016. Hlm. 76-90. 
[9] Smith, J., \& Roberts, S. (2011). Vital sign for nurses an introduction to clinical observations. London: Wiley-Black.

[10] Suryati Ida, Esma Wita. (2015). Hubungan Mekanisme Cedera dengan Nilai GCS pada Pasien Cedera Kepala di IGD Rumah Sakit Umum Dr. Achmad Moctar Bukittinggi. Stikes Perintis Sumbar.

[11] Wahyudianto R., Haryuni Sri, Lutfi Erik Irham. (2014). Revised Trauma Score Dengan Kejadian Mortalitas Pada Pasien Cedera Kepala. Fakultas Ilmu Kesehatan Universitas Kediri : Gambiran kota Kediri.

[12] Widyaswara P.A., Wihastutin T.A., Fahtoni M. (2016). Analisis faktor-faktor yang berhubungan dengan outcome pasien cedera kepala di IGD RSUD Prof. Dr. Margono Soekardjo Purwokerto. Jurnal Ilmiah Kesehatan Keperawatan. 12930; 154-164.

[13] World Health Organitation. (2015). Rood Traffic Injuries. Diakses tanggal 20 Oktober 2019. Dari http://www.who.int/mediacentre/factsheets/fs358/e. 